\title{
Are There Effective Accounting Ways to Determining Accurate Accounting Tools and Methods to Reporting Emissions Reduction?
}

\author{
Ali Ahmed Ali Almihoub ${ }^{1}$, Joseph M. Mula ${ }^{1} \&$ Mohammad Mafizur Rahman ${ }^{1}$ \\ ${ }^{1}$ School of Accounting, Economics and Finance, Faculty of Business and Law, University of Southern \\ Queensland, Australia \\ Correspondence: Ali Ahmed Ali Almihoub, School of Accounting, Economics and Finance, Faculty of Business \\ and Law, University of Southern Queensland, Australia. E-mail: ali.almihoub@usq.edu.au
}

\author{
Received: February 4, 2013 Accepted: March 20, 2013 Online Published: March 28, 2013 \\ doi:10.5539/jsd.v6n4p118 URL: http://dx.doi.org/10.5539/jsd.v6n4p118
}

\begin{abstract}
Over the last century, many studies have used accounting methods and tools in focusing on environmental issues. This paper introduces readers to developments within the appropriate accounting tools designed to support firms and sectors reduction energy use as well as reducing greenhouse gases (GHGs) emissions. Current practice of traditional accounting (to date) has not covered environmental costs. Using Activity Based Costing could help firms to increase their understanding of sustainability and how to develop way to incorporate opportunity costs of environmental activities which are becoming significant issues on stakeholders. Moreover, an environmental management accounting approach can enhance information available on emissions to be more accurate. The net present value and internal rate of return also are considered the biggest hurdles to enhancing sustainability in business. This paper concludes that there is considerable potential to use environmental management accounting approach which is based on actual data to obtain more accurate information.
\end{abstract}

Keywords: conventional accounting, activity based costing, internalizing and externalities, environmental management accounting, net present value and internal rate of return

\section{Conventional Accounting}

Traditionally accounting contains two elements: financial accounting and management accounting. Financial accounting is designed to provide an analysis of financial performance to guide the decision-making process on investments and performance management and also to support the information needs of external stakeholders (IFAC, 2005; Petcharat \& Mula, 2010a; UNDSD, 2001c). Financial accounting has been designed to achieve systematic discipline in the organisation of data. On the other hand, management accounting to a large extent is used for decision making internally to measure the cost of inputs (materials and labour), while addressing all other costs overheads. Environmental costs have been addressed in management accounting as overheads costs and thus been hidden from production and service operations (Hill, McAulay, \& Wilkinson, 2006). Accounting involves encouraging the adoption of standards of measurement in environmental data (Ascui \& Lovell, 2011b). Thus it also encourages the development of comprehensive and harmonious data sets over time, that may facilitate global comparisons (Alfieri \& Olsen, 2007).

In conventional accounting, a combination of environmental and non-environmental costs are in the accounts as overheads and they are "hidden" from the management (Jasch, 2003). There is strong evidence that management have a tendency to reduce the size and growth of these costs. Through the identification, evaluation and distribution of environmental costs, environmental accounting allows management to identify opportunities for cost savings and to calculate actual costs of projects and investments (Parker, 1997). Examples are savings that can lead to replacing toxic organic solvents from non-toxic alternatives, thus eliminating the high costs and increasing regulatory reporting of hazardous waste treatment and other costs associated with the use of toxic substances. Many other examples to deal with the more efficient use of materials, and to highlight the fact that waste is expensive and not because of the disposal fees but because of wasted material purchase value (Jasch, 2003).

Generally, firms spend large amounts of financial resources to reduce and control pollution. In most cases, these costs represent the most obvious and the most easily measured costs related to the environment. However, these costs are just the tip of the iceberg. Hidden environmental costs could be greater than costs to reduce pollution 
and controls; finding and eliminating these hidden costs may provide important opportunities to improve decision making, business planning and overall efficiency (Staniskis \& Stasiskiene, 2006).

Conventional cost accounting require more effort to improve reforms in accounting procedures (Li, 2004). Given the tendency of prior companies not to shed light on environmental costs, there are many studies (Burritt \& Saka, 2006; Ditz, Ranganathan, \& Banks, 1995), that have attempted to find answer to the following questions; What are environmental costs? Which classes of environmental costs are potentially important to business? Are environmental costs significant for particular organizations? For obtaining answers to these questions, environmental costs could be categorized in several different ways. Therefore, academics have classified environmental costs in five tiers, these classifications appear to receive special attention based on (Burritt \& Saka, 2006):

“(1) Analysis of conventional cost accounting methods and measurement (Horngren et al., 2010; Schaltegger \& Burritt, 2000) such as job and process; direct and indirect; historical and standard; fixed and variable; ordinary and extraordinary;

(2) Extending the classification of costs (Burritt, 2004) to include conventional, indirect hidden, less tangible, contingent; and societal costs (negative externalities);

(3) Quality costs and the environment (Burritt \& Saka, 2006) analysis of prevention, assessment (appraisal), control (internal failure) and external failure environmental costs;

(4) Life cycle and activity costs (Kreuze \& Newell, 1994): life cycle research and development, design, production; activity based unit, batch, product sustaining and facility level costs based on a wider set of cost drivers than conventional management accounting recognizes;

(5) Target audience (Burritt, Hahn, \& Schaltegger, 2002) such as internal (managers and employees); external (shareholders, tax agencies, environment agencies, suppliers, creditors, general public, local communities and NGOs)."

Environmental cost is also used to measure accounting business management and performance by the introduction of the Activity Based Costing (ABC) method.

\section{Activity Based Costing}

$\mathrm{ABC}$ can be defined as a costing method (based on calculating operating costs) that classifies activities in an association and appoints each activity cost to all services and products regarding to the real consumption. In other words, it measures all the activities of enterprise resources consumption including the exact cost of resources that are consumed in operations, and then select cost drivers (Nachtmann \& Al-Rifai, 2004). The important idea for $\mathrm{ABC}$ model is to consider the cost of an enterprise environment (Cagno, Micheli, \& Trucco, 2012). Arguably, calculating environmental cost could be the first step of the environmental costs incurred (Lindskog et al., 2011). In estimating environmental cost, some criteria should be taken into account. For example, the occurrence of the process should be associated with the environment, compliance with the rules of definability, reliability and measurability. Moreover, the period of belonging of cost-effectiveness should be determined. It is noticed that application of environmental cost by using $\mathrm{ABC}$ approach can be recognized the cost of an enterprise environment.

In recent years firms have increasingly paid attention to measure and reduce the environmental footprint of products and activities (Lindskog et al., 2011). In using ABC system distribution, environmental costs are essential. In fact, these importance comes from the ability of allocating environmental certain expenditures to pose environmental costs of products (Rivero \& Emblemsvåg, 2007). However, there are some reasons behind making existing accounting approaches difficult to use for calculating environmental costs. For example, there are environmental costs, which are not quantifiable and these costs may face some difficulties to match specific income. Therefore, it is important to identify how to separate ecological costs from indirect costs to be measured and accurately assigned for different cost account (Innes, Mitchell, \& Sinclair, 2000). With applying ABC, it is possible to determine cost of operating cost library, in relation to rationally allocate of ecological costs and the cost drivers.

The use of $\mathrm{ABC}$ method allows allocating environmental costs specifically. This allocation can be achieved by the following (Jing \& Songqing, 2011):

$>$ Analysing environmental costs of the events and identifying activities.

$>$ Environmental costs should be assigned to each process. In this respect, different groups should be divided according to their characteristics and functions to reduce the number of indirect cost allocated 
to simplify calculations.

$>$ Determining the drivers of environmental cost, which are considered the critical factor. This factor leads to occurrence of environment cost.

$>$ Allocating and calculating cost drivers of the operations library cost.

$>$ It should be considered that some library operating costs returns to the products. Using cost drivers allocation operating costs library and the number of used process drivers can calculate the environmental costs. The specific formula might be shown as follows:

The environmental cost shared by certain product

$=$ cost driver allocation ratio $\times$ operation number of the product consumed

A product's environmental costs $=\Sigma$ the cost should be shared by the product in each activity center

Understanding factors that affect costs and allocation costs is important foundation for ABC approach. A deep understanding of the cost structure and factors affecting activity based costing facilitate discloser of environmental costs, whereas $\mathrm{ABC}$ needs to be an integrated framework for management strategy, including drivers and amount of revenue, which delivers a balanced scorecard. Therefore, organizations ultimately benefit from these measurement approaches such as fiscal discipline and investment that comes from the adoption of a shareholder value approach. The importance of $\mathrm{ABC}$ is that it enhances the understanding of organisation processes associated with every product (UNDSD, 2001). ABC improves internal cost calculations through the allocation of costs that are commonly found in public accounts of activities of contaminated products, and is determined by quantitative assessment procedures in life cycles (Wahyuni, 2009).

Berry (2005) states that management accounting provides companies with a way to create cost information to support business decision-making in every part of business management, planning, and control to meet business objectives. In addition, management accounting has been used to measure business performance management through the introduction of the $\mathrm{ABC}$ method to capture the full costs of products and provide information on the cost of internal decisions on investment (Armstrong, 2006). ABC makes the distribution of costs of activities to support the most accurate pricing of products and services. ABC can play an important role in cost analysis, identification and allocation. $\mathrm{ABC}$ currently is developing in terms of green accounting and environmental accounting to find estimating methods to reduce the negative impacts on the environment and ecosystems (Capusneanu, 2009). Firms have adopted the $\mathrm{ABC}$ method with respect to the application of the cost of distribution and analysis. Thus $\mathrm{ABC}$ could help firms to increase their understanding of sustainability and how to develop ways to incorporate the opportunity costs of environmental activities.

$\mathrm{ABC}$ method can expand firms' scope of application from conventional management accounting to becoming the main approach in developing concepts of green accounting and social management systems. That makes $\mathrm{ABC}$ able to assist to identify and allocate costs of environment, which are related to sustainable environment costs and social impacts (Bartolomeo et al., 2000). Principles of ABC identifies the real production costs which facilitate establishment of eco-efficiency as a consequence of cost savings by reducing inputs (such as materials, energy, water, waste) and non-product outputs such as emissions and waste, and/or disposal of waste (Capusneanu, 2009; Da Silva \& Amaral, 2009). The development of ABC approach can use management accounting best practices to support control of production costs, quantifying improvements in productivity (Kaplan \& Johnson, 1987). Also, management accounting systems could be helpful in providing accurate information about environmental costs to help internal management decisions on products and pricing (Kaplan \& Johnson, 1987).

Kaplan and Norton (2001) have stated that there is relationship between balanced scorecard and other financial and costs measurement initiatives, which are shareholder value metrics, $\mathrm{ABC}$ and quality programs. This has concluded with proposals for more additional research to the measurement and management systems. Therefore, firms for attempting strategic alignment may focus on different ways, at different steps and different sequences to achieve sustainability performance at a company and project level. They use a common set of principles that are called Principles of a Strategy-Focused Organization (Kaplan \& Norton, 2001, p. 147) that are: "translate the strategy into operational terms translation organizations strategy in the logical architecture of the strategy map and Balanced Scorecard to determine in detail the critical elements of the growth strategies; align the organization strategic organizations made up of many sectors, business units, and specialized departments, each with its own operations, and often its own strategy; make strategic task of each every day for understanding of senior executives and senior leadership teams for adoption organizations that they cannot implement a new strategy in itself; make strategy a continuous process that most organizations building management operations around their budget and operating plan, and finally mobilization leadership for change'. Thus, through the 
expansion of demand for $\mathrm{ABC}$, businesses can improve their ability to cost products fully (full cost accounting) and then firms could create more accurate costs of environment and social impacts to make better decisions on management and cost savings and reporting initiatives (Jasch, 2009). Therefore, companies can create better jobs and improve economic performance, as well as enhancing their opportunities, development of environmental, social efficiency and address concerns of stakeholders and the public.

Social and environmental costs among operations and services can be treated by $\mathrm{ABC}$ method. Nachtmann and Al-Rifai (2004) noticed that ABC has used successfully in managing the costs and avoids the allocation of public expenditures. Also, they found that $\mathrm{ABC}$ does not measure environmental costs and social impacts correctly and costs of the accurate products. Thus, firms need to provide cost information to improve financial reports. However, they are unable to complete cost products (Englund \& Gerdin, 2008). Geri and Ronen (2005) argue that $\mathrm{ABC}$ approach could not estimate the profits when product costs are complex. Therefore, corporations might not be able to develop business decision-making on managing costs (Geri \& Ronen, 2005; Innes et al., 2000). Although, the need for a detailed analysis of the operations, cost of objects and drivers require considerable effort on all the parts of the corporation, using $\mathrm{ABC}$ might provide more detailed information on environmental costs accurately for calculating the environmental cost of firm choice (Cagno et al., 2012). It can be concludes that firms requires more efforts without obtaining better results, associated problematic and costly design, implementation and operation of the systems needed for ABC.

Over the last few years, accounting for carbon has developed to be one important area which is preferred by economy sectors as well as firms, to gain more accurate and credible information for internal management and stockholders (Burritt, Schaltegger, \& Zvezdov, 2011; IPCC, 2005). It could become clearer that financial risks are high. For example, in 2010 transactions in carbon markets in USA reached US $\$ 142$ billion. The Copenhagen agreement has promised developing countries assistance to the tune of US\$100 billion/year by 2020 (Ascui \& Lovell, 2011b; UN, 2009). Therefore, carbon accounting includes many tasks that make it credible to operation activities. This is related to reduce emissions and maintain the environment, which needs efforts and expertise to standardize and develop environmental accounting. Environmental accounting has many developments how it discloses the carbon. These various developments have environmental cost; contain different details that depended on natures and activities of the firms.

There is a broad definition of environmental cost which may be incomplete, despite the monetary factors implicit in reference to the character of financial instruments and transactions. There are other methods using monetary values that may be reflected in the management accounting of carbon, for example in terms of the cost of introducing carbon in the capital operational budget or cost accounting (Burritt et al., 2011). In setting, costs of abatement environmental influences, emissions trading revenues, capital investment accounts associated with cleaner production and eco-friendly products provide the needed information for monetary decision-making. In addition, estimating and reporting effects of climate change on the organization also can be determined in carbon accounting, which include monitoring and detection of actions taken by strategic management to address these impacts. These effort by individual, organizations, countries, United Nations and other institutions around the world have developed many programs relating to green accounting (Buchner, Brown, \& Corfee-Morlot, 2011)

The United Nations program called Clean Development Mechanism (CDM) in the market, is working to include measuring emission reductions relative to baseline hypothetical, and other operations associated with the establishment of tradable goods and carbon credit (Smith et al., 2009) International Accounting Standards Board (IASB) is interested in accounting for tradable emission rights and obligations which is increasing under emissions trading schemes (Ascui \& Lovell, 2011a). For a growing number of companies reporting to the carbon disclosure project, and climate record or other plans similar, it involves measurement and disclosure of GHGs emissions that firms accept with varying degrees of responsibility (Kolk, Levy, \& Pinkse, 2008). Although, has been improvements in sustainability accounting there is a need for more development in this filed.

Quantitative life cycle assessment of environmental accounting systems requires a combination of quantitative value of environmental impacts associated with a project (De Beer \& Friend, 2006). Assessment could be at any one of three points. First, develop a list of energy-related material inputs and environmental data. Then assess the environmental and social impacts associated with specific inputs and releases. Finally, interpret results to make informed decisions. Together a quantitative life cycle assessment and an environmental accounting system provide an overview of environmental impacts of a project and a more accurate picture of the true environmental trade-offs, with associated financial implications, in the selection of product and process (Bowen \& Wittneben, 2011; Environmental Protection Agency, 2001). 
The total cost assessment from an environmental accounting system includes quantity of environmental life cycle assessment considered as part of the product or process evaluations (Norris, 2001). Environmental accounting systems have the ability to assess the full life-cycle in question, and to consider all environmental and social aspects from the extraction of raw materials stage to the end of life of the product or process (Beer, 2005). It underpins the understanding of health costs, environmental and human impacts of a project, which represent both internal and external cost (Little, 2000).

\section{Internalities and Externalities}

The global economy operates under the pressure of market forces that, until recently has not complied with environmental principles. Before global environmental awareness, prices included traditional costing from accounting information that was built from an economic sense, without recognising the impact on the environment. After the impact of global environmental awareness, decision-makers were forced to view and include costing aspects that pertain to different global environmental systems (Bolinger, Wiser, \& Golove, 2006).

Australia and Japan have experience through implementation of environmental impact reduction, which are lowering the exploitation of their natural environment (Dascalu, Caraiani, Lungu, Colceag, \& Guse, 2010). During their experiences, the aim of inclusion of external factors becoming an internalised cost achieved benefits, which otherwise would not have been noticed or accounted for during the environmental balance of corporate governance. This allows the companies to achieve considerations in the decision-making process that could enhance profitability (Guşe, Dascălu, Caraiani, Lungu, \& Colceag, 2010). It leads to ensuring the survival of an organisation in the future by understanding the potential responsibility and risk scenarios (Gale \& Stokoe, 2001; Guşe et al., 2010). In addition, organisation could be able to inform stakeholders on environmental and health impacts of economic activities of an organization (Gale \& Stokoe, 2001; Guşe et al., 2010).

The externally-generated cost estimates are from environmental damage caused by an organisation during its activities in a specific location (Bockel, Sutter, Touchemoulin, \& Jönsson, 2012; Dascalu et al., 2010). From a standpoint of economic theory, this approach estimates the cost of damage and the value of damage (to health) for those who bear the damage. The approach uses the value of the cost of damage from their loss of ability to estimate external costs. However, if companies measure reductions in environmental damage as far as 'optimal' (i.e. the extent to which they reduce the total cost of internal and external) then, the marginal cost of external factors (the additional costs of the last unit and the damage) is equal to the cost of internal margins. On this basis, in some cases, marginal external costs can be equal to the marginal internal costs and estimated accordingly. This technique is called internalising the cost of control approach (Guşe et al., 2010).

Accounting concerns for external costs in practice are increasingly using "shadow prices" (a monetary unit for each tonne of greenhouse gas emissions) in capital budgeting decisions by companies (Dascalu et al., 2010; Gale $\&$ Stokoe, 2001). This reflects the view that, although there are currently no such costs imposed on companies, it is likely that they will be in the future (Gale, 2001; Jaffe, Newell, \& Stavins, 2005).

It may be more practical and realistic for a company to take into account that external cost as internal costs are imminent. In other words, it can be assumed that the end of each category of external costs will be reflected in internal costs (Figge \& Hahn, 2004). Dascalu et al. (2010) state that external costs become internal costs and can increase from zero (when the costs are purely external) to amounts that can meet or even exceed the amounts of the initial external cost. So, instead of accounting for external costs directly and immediately, external costs can have different configurations to be included in internal costs (i.e. external costs become internal costs). Formations of future time costs are still implications from current capital budgets and other relevant resolutions that include environmental accounting (Uno \& Bartelmus, 1998). Therefore, it is vital to sitting environmental accounting to help achieve working environmentally

Environmental accounting illustrates measures and reports on allocation of environmental resources, costs, expenses and risks of different industrial groups, to departments and specific projects, activities, or processes (Dascalu et al., 2010). With respect to increasing the base of environmental accounting, there are three techniques considered important: Total Cost Accounting (TCA), Full Cost Assessment (FCA), and Life Cycle Analysis (LCA), these are in the context of $\mathrm{ABC}$ system that measured to be a technique aimed at the economic analysis of a business's indirect costs (Dascalu et al., 2010; Gluch \& Baumann, 2004).

TCA refers to the analysis of long-term, comprehensive financial analysis for the full range of costs and savings for investment (Gluch \& Baumann, 2004). The general framework of the TCA technique represents an approach to an expanded traditional financial analysis (Dascalu et al., 2010). It is a tool for the preparation of feasibility studies that facilitate the identification and analysis of project costs and internal savings. TCA builds on the traditional models of cost accounting by including financial costs of direct and indirect costs recognised, units 
recognised including costs of compliance in the future, penalties and fines, the launch of responses, treatments, and the time value of money. These costs are also sources of great concern in accounting models (Lovell \& MacKenzie, 2011). Traditional full cost environmental accounting (FCEA) considers the identification, evaluation, and distribution of traditional cost and organization sustainability (Dascalu et al., 2010; Frame \& Cavanagh, 2009). From a social perspective, environmental accounting includes monitoring global performance; therefore, monitoring global performance broadens FCA (Bennett, James, \& Klinkers, 1999; Dascalu et al., 2010). Environmental accounting is recognized by professionals and academics. It includes traditional costs, as well as the internal and external costs socially borne by society (Guşe et al., 2010). This approach provides an opportunity to take into account external costs that may reflect real marginal costs.

Life Cycle External Costs Assessment (LCECA) attempts to impose costs of the life cycle model for estimating and linking as well as implications of these costs in all life cycle stages in the product (Plesch, 2003). LCECA aims to identify various external factors. This involves each stage of a product's life cycle, to determine the relationship between them. The assessment includes total cost of a product and costs of any developments in the life cycle model. The results from the assessment are compared to an existing product with their alternatives and the effects of external factors in the environmental design of products (Dascalu, Caraiani, \& Lungu, 2007). Therefore, to maintain the environment in order to organizations continue accounting sustainability must be used.

\section{Sustainability Accounting}

Accounting has developed the word 'sustainability' as the basis of measuring sustainable development of business in the form of environmental and social performance (Jasch \& Stasiskiene, 2005). Sustainability accounting provides firms with sustainable business tools to manage environmental and social costs, as well as offering information on the costs of business for decision-making process and detection of unsustainable practices (UNDSD, 2001). Sustainability accounting attempts to maintain a balance between human activities and ecological patterns to keep development continuing in the long run (Berkel, 2003). Sustainability accounting gave scientists the various measures they need to improve long-term environmental and social performance. Thus, for the purpose of clarifying the benefits of sustainability accounting it is important to analyse the costs and benefits and presented to managers.

A study conducted in Australia indicates that cost-benefit analysis is an important accounting tool that managers can use to evaluate projected environmental impacts of various actions (Rubin, Rao, \& Berkenpas, 2001; Wilmshurst \& Frost, 2001). Most companies do not identify the extent of their environmental costs since these costs are usually hidden in various broad administrative or manufacturing overhead accounts (Petcharat \& Mula, 2010b; Seidel \& Thamhain, 2002). Therefore, sustainability accounting can make accounting more appropriate with surrounding developments.

Environmental accounting includes the identification, measurement, and allocation of environmental costs, the integration of these costs into an industry, determination of environmental liabilities, if any, and finally, communicating this information to a corporation's stakeholders as part of general financial and sustainability statements (Pramanik, Shil, \& Das, 2007). Environmental accounting systems define, measure, analyse, and convey information regarding environmental aspects of corporate activities (Burritt, Hahn, \& Schaltegger, 2002). Environmental accounting identifies environmental costs, capitalises costs, and measures liabilities (Pramanik et al., 2007). This approach helps firms and sectors to develop their performance environmentally and economically as well as for disclosure of their emissions. Using an environmental management accounting approach can support development of more accurate information about sustainability and emissions' reductions.

\section{Environmental Management Accounting}

Carbon accounting for emissions is practically and technically complex (Young, 2010). Input-output analysis in particular, identifies potential resource and energy savings. It is frequently the first step in an environmental audit process, and it could facilitate product invention and pollution preventing strategies, especially when it forms part of a product and/or process life cycle analysis (Jasch, 1993). Input-output analysis can measure sustainability or unsustainability helping to provide a transparent account of physical flows into and out of a process, and enabling analysis of environmental impact and eventually sustainability strategies (Gray, 1994). Environmental management accounting (EMA) has emerged in recent decades as a reaction to the growth of environmental problems. Roman, Roman, and Manole (2006) point out:

EMA can be defined as the identification, collection, estimation, analysis, internal reporting, and use of materials and information concern of energy flow, and environmental and other costs for both conventional and environmental decision making within an organization. 
Today, it is a broadly used tool in balancing the interaction between economic, environment, social, and technological factors in the development process to complete conditions for a sustainable environment (Erickson, 2010). EMA collects data necessary to understand the marginal cost of implementing abatement. Scavone (2006) states, firms are profit seeking and thus always looking for a return on any investment, particularly from emission abatement interventions. Thus, analysts need to find a range of options and choose those that will attain emission reductions contained in at least NPV costs, to account for time value of money.

\section{Net Present Value and Internal Rate of Return}

Payback on investments is assessed by business and industry before a decision to implement. Process and equipment modifications, which can be implemented by many companies to reduce energy consumption might be more costly than new capital projects (Hardisty, 2009). In some cases, examining energy efficiency projects while considering carbon costs is not likely to provide internal rates of return that meet hurdle rates, and then can be rejected. As a result, many companies do not accept a lot of worthwhile environmental projects. Although the profitability of these projects are positive (or cost-negative), they are not profitable enough to meet IRR goals. Thus, environmental and social costs are almost always excluded (Hardisty \& Ozdemiroglu, 2005; Pearce \& Warford, 2001). Use of NPV and IRR are considered the biggest hurdles to enhancing sustainability in business.

Calculating the costs of pollution control delivered by some measures requires consideration of cost profiles that extend over a number of years (Moran et al., 2008). A consistent treatment of current alternatives involves deducting the cost of the treatment time. However, the discount rate can be significantly different by case in calculating the cost-effectiveness of mitigation options (Moran et al., 2008). The question is then, essentially, what discount rate should be used? Should it be the social discount rate to reflect the preference of society to gain benefits now, deferring costs to a later time, which could lead firm to be more appropriate when it deals with environmental issues (Beaumont \& Tinch, 2004). There is no consensus in the literature on the preferable discount rate but the social discount rate is purported to be mostly used (Sweeney \& Weyant, 2008). A common social discount rate used is 3.5\% (Kesicki, 2010; Kesicki \& Strachan, 2011). However, this rate can be modified to reflect other rates used to incorporate time preferences (e.g. the study of Greater Geelong used rates ranging from $12 \%$ to $38 \%$ ), which should consider the opportunity cost of private capital.

Emission reduction measures will generally run over a period of years, making it necessary to estimate the age of capital equipment for the purpose of calculating the period of recovery -payback period (PP) (Wagner et al., 2012). This determines the time required to recover the capital invested in the project through annual returns. PP is an index which indicates the level of profitability of an investment. The best investment is one with the shortest recovery period. The PP rule is, the project should be acceptable if the project is less than PP from other projects; if the PP is higher than the PP of other projects, the project can be rejected (Ross et al., 1999). However, to be acceptable to an organization, a positive NPV is sought from any investment in emission reduction technologies (Hardisty, 2009). IRR and PP are indicators that help to choose the best investment, but they have some problems that can be found in the literature (e.g. Ross et al., 1999).

\section{Conclusion}

Global warming continues to be a significant issue on both national and international scale. With this importance, accounting for GHG emissions attempts to find appropriate tools to help decrease these emissions. This need for emissions reduction has drawn the attention of many organizations. Sectors and firms have adopted some accounting methods to reduce their emissions. Reduction measures should fully rely on an appropriate environmental accounting system which is accurate, consistent over the passage of time and place. Motivations behind this focus are that the current practice of traditional accounting (so far) has not covered environmental costs and not identified appropriate methods. The paper has shown that, accounting can help companies by using $\mathrm{ABC}$ to increase their understanding of how to reduce emissions as an integrated way of identifying opportunity costs of environmental activities that have become important issues for stakeholders. Using an environmental management accounting approach can support the reliability of emissions information. This study also assesses and suggests future directions in which research on using concepts such as environmental management accounting which is based on actual data to reduce GHG to provide valuable insights for practice. 


\section{References}

Alfieri, A., \& Olsen, T. (2007). Integrated Environmental and Economic Accounting. Paper presented at the The 2nd meeting of the Oslo Group on Energy Statistics, New Delhi. Retrieved from http://www.ssb.no/ocg/integrated_environmental.pdf

Armstrong, M. (2006). Handbook of Management Techniques: A Comprehensive Guide to Achieving Managerial Excellence and Improved Decision Making 3rd edn, Kogan Page London. Retrieved April 5, 2012, from http://common.books24x7.com.ezproxy.usq.edu.au/book/id_18795/book.asp

Ascui, F., \& Lovell, H. (2011a). As frames collide: making sense of carbon accounting. Accounting, Auditing \& Accountability Journal, 24(8), 978-999. http://dx.doi.org/10.1108/09513571111184724

Ascui, F., \& Lovell, H. (2011b). Carbon accounting and the construction of competence. Journal of Cleaner Production, 36, 48-59. http://dx.doi.org/doi:10.1016/j.jclepro.2011.12.015

Bartolomeo, M., Bennett, M., Bouma, J. J., Heydkamp, P., James, P., \& Wolters, T. (2000). Environmental management accounting in Europe: current practice and future potential. European Accounting Review, 9(1), 31-52. http://dx.doi.org/10.1080/096381800407932

Beaumont, N., \& Tinch, R. (2004). Abatement cost curves: a viable management tool for enabling the achievement of win-win waste reduction strategies? Journal of environmental management, 71(3), 207-215. http://dx.doi.org/10.1016/j.jenvman.2004.03.001

Beer, P. F. F. (2005). Environmental accounting: A management tool for enhancing corporate environmental and $\begin{array}{lllll}\text { economic } & \text { Eerformance. } & \text { Ecological }\end{array}$ http://dx.doi.org/10.1016/j.ecolecon.2005.07.026

Bennett, M., James, P., \& Klinkers, L. (1999). Sustainable measures: evaluation and reporting of environmental and social performance. Greenleaf Publishing.

Berkel, R. (2003). Managing for Sustainable Development: Using environmental management accounting and sustainable development reporting. CPA congress, 21(23), 1-18.

Berry, L. E. (2005). Management Accounting Demystified. United States: McGraw-Hill Companies.

Bockel, L., Sutter, P., Touchemoulin, O., \& Jönsson, M. (2012). Using Marginal Abatement Cost Curves to Realize the Economic Appraisal of Climate Smart Agriculture Policy Options. EasyPol Module.

Bolinger, M., Wiser, R., \& Golove, W. (2006). Accounting for fuel price risk when comparing renewable to gas-fired generation: the role of forward natural gas prices. Energy Policy, 34(6), 706-720. http://dx.doi.org/10.1016/j.enpol.2004.07.008

Bowen, F., \& Wittneben, B. (2011). Carbon accounting: Negotiating accuracy, consistency and certainty across organisational fields. Accounting, Auditing \& Accountability Journal, 24(8), 1022-1036. http://dx.doi.org/10.1108/09513571111184742

Buchner, B., Brown, J., \& Corfee-Morlot, J. (2011). Monitoring and tracking long-term finance to support climate action. International Energy Agency, OECD.

Burritt, R., Hahn, T., \& Schaltegger, S. (2002). Towards a comprehensive framework for environmental management accounting-Links between business actors and environmental management accounting tools. Australian Accounting Review, 12(27), 39-50. http://dx.doi.org/10.1111/j.1835-2561.2002.tb00202.x

Burritt, R. L. (2004). Environmental management accounting: roadblocks on the way to the green and pleasant land. Business Strategy and the Environment, 13(1), 13-32. http://dx.doi.org/10.1002/bse.379

Burritt, R. L., Hahn, T., \& Schaltegger, S. (2002). Towards a comprehensive framework for environmental management accounting - Links between business actors and environmental management accounting tools. Australian Accounting Review, 12(27), 39-50. http://dx.doi.org/10.1111/j.1835-2561.2002.tb00202.x

Burritt, R. L., \& Saka, C. (2006). Environmental management accounting applications and eco-efficiency: case studies from Japan. Journal of Cleaner Production, 14(14), 1262-1275. http://dx.doi.org/10.1016/j.jclepro.2005.08.012

Burritt, R. L., Schaltegger, S., \& Zvezdov, D. (2011). Carbon management accounting: explaining practice in leading German companies. Australian Accounting Review, 21(1), 80-98. http://dx.doi.org/10.1111/j.1835-2561.2010.00121.x

Cagno, E., Micheli, G. J., \& Trucco, P. (2012). Eco-efficiency for sustainable manufacturing: an extended 
environmental costing method. Production Planning \& Control, 23(2-3), 134-144. http://dx.doi.org/10.1080/09537287.2011.591628

Capusneanu, S. (2009). Implementation Opportunities of Green Accounting for Activity-Based Costing (ABC) in Romania. Theoretical and Applied Economics, 1(518), 57-62.

Da Silva, P. R. S., \& Amaral, F. G. (2009). An integrated methodology for environmental impacts and costs evaluation in industrial processes. Journal of Cleaner Production, 17(15), 1339-1350. http://dx.doi.org/10.1016/j.jclepro.2009.04.010

Dascalu, C., Caraiani, C., \& Lungu, C. I. (2007). Eco-cost challanges for environmental protection. Journal of Environmental Protection and Ecology, Master Journal List Thomson Scientific. Retrieved from http://thomsonscientific.com/cgibin/jrnlst/jlresults.cgi?

Dascalu, C., Caraiani, C., Lungu, C. I., Colceag, F., \& Guse, G. R. (2010). The externalities in social environmental accounting. International Journal of Accounting and Information Management, 18(1), 19-30. http://dx.doi.org/10.1108/18347641011023252

De Beer, P., \& Friend, F. (2006). Environmental accounting: A management tool for enhancing corporate environmental and economic performance. Ecological Economics, 58(3), 548-560. http://dx.doi.org/10.1016/j.ecolecon.2005.07.026

Ditz, D. W., Ranganathan, J., \& Banks, R. D. (1995). Green Ledgers: Case studies in corporate environmental accounting. World Resources Institute.

Englund, H., \& Gerdin, J. (2008). Structuration theory and mediating concepts: Pitfalls and implications for management accounting research. Critical perspectives on accounting, 19(8), 1122-1134. http://dx.doi.org/10.1016/j.cpa.2007.06.004

Environmental Protection Agency. (2001). Introduction to LCA, United States Environmental Protection Agency and Science Applications International Corporation. Retrieved April 4, 2012, from http://www.epa.gov/ORD/NRMRL/lcaccess.htm

Erickson, P. (2010). Estimates of Future Supply of International Greenhouse Gas Offsets: A Critical Review.

Figge, F., \& Hahn, T. (2004). Sustainable value added - measuring corporate contributions to sustainability

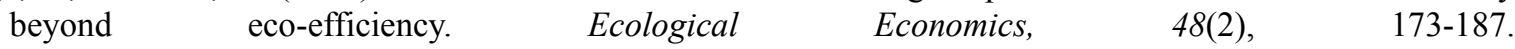
http://dx.doi.org/10.1016/j.ecolecon.2003.08.005

Frame, B., \& Cavanagh, J. (2009). Experiences of sustainability assessment: An awkward adolescence.

Gale, R. J. P., \& Stokoe, P. K. (2001). Environmental cost accounting and business strategy. Handbook of environmentally conscious manufacturing, 119-137. http://dx.doi.org/10.1007/978-1-4615-1727-6_6

Gale, R. (2001). Environmental Cost Accounting and Business Strategy. In M. Chris (Ed.), Handbook of Environmentally Conscious Manufacturing (Kluwer Academic Publishers). http://dx.doi.org/10.1007/978-1-4615-1727-6_6

Geri, N., \& Ronen, B. (2005). Relevance lost: the rise and fall of activity-based costing. Human Systems Management, 24(2), 133.

Gluch, P., \& Baumann, H. (2004). The life cycle costing (LCC) approach: a conceptual discussion of its usefulness for environmental decision-making. Building and Environment, 39(5), 571-580. http://dx.doi.org/10.1016/j.buildenv.2003.10.008

Gray, R. (1994). Corporate reporting for sustainable development: accounting for sustainability in 2000AD. Environmental Values, 3(1), 17-45. http://dx.doi.org/10.3197/096327194776679782

Guşe, G. R., Dascălu, C., Caraiani, C., Lungu, C. I., \& Colceag, F. (2010). Exploring eco-costs and externalities absorption policies and procedures in the context of global warming.

Hardisty. (2009). Analysing the role of decision-making economics for industry in the climate change era. Management of Environmental Quality: An International Journal, 20(2), 205-218. http://dx.doi.org/10.1108/14777830910939507

Hardisty, P., \& Ozdemiroglu, E. (2005). The economics of groundwater remediation and protection: CRC.

Hill, M., McAulay, L., \& Wilkinson, A. (2006). Emissions trading and the management accountant - lessons from the UK emissions trading scheme. Research Executive Summaries Series, 2(13), 1-6. 
Horngren, C. T., Foster, G., Datar, S. M., Rajan, M., Ittner, C., \& Baldwin, A. A. (2010). Cost Accounting: A Managerial Emphasis. Issues in Accounting Education, 25(4), 789-790. http://dx.doi.org/10.2308/iace.2010.25.4.790

IFAC. (2005). Environmental Management Accounting, International Federation of Accountants, New York.

Innes, J., Mitchell, F., \& Sinclair, D. (2000). Activity-based costing in the UK's largest companies: a comparison of 1994 and 1999 survey results. Management Accounting Research, 11(3), 349-362. http://dx.doi.org/10.1006/mare.2000.0135

IPCC. (2005). Intergovernmental Panel on Climate Change. IPCC special report on carbon dioxide capture and storage. IPCC. Retrieved from www.ipcc.ch/pdf/special-reports/srccs/

Jaffe, A. B., Newell, R. G., \& Stavins, R. N. (2005). A tale of two market failures: Technology and environmental policy. Ecological Economics, $164-174$. http://dx.doi.org/10.1016/j.ecolecon.2004.12.027

Jasch, C. (1993). Environmental information systems in Austria. Social and Environmental Accounting, 13(2), 7-9. http://dx.doi.org/10.1080/0969160X.1993.9665791

Jasch, C. (2003). The use of Environmental Management Accounting (EMA) for identifying environmental costs. Journal of Cleaner Production, 11(6), 667-676. http://dx.doi.org/10.1016/S0959-6526(02)00107-5

Jasch, C. (2009). Environmental and material flow cost accounting. Principles and procedures. EMAN-Eco-efficiency in Industry and Science 25: Springer-The Netherlands, p. 194.

Jasch, C., \& Stasiskiene, Z. (2005). From environmental management accounting to sustainability management accounting. Environmental research, engineering and management, 4(34), 77-88.

Jing, H., \& Songqing, L. (2011). The Research of Environmental Costs Based on Activity Based Cost. Procedia Environmental Sciences, 10, 147-151. http://dx.doi.org/10.1016/j.proenv.2011.09.026

Kaplan, R. S., \& Johnson, H. T. (1987). Relevance Lost: The rise and fall of management accounting. Boston: Harvard Business School.

Kaplan, R. S., \& Norton, D. P. (2001). Transforming the balanced scorecard from performance measurement to strategic management: Part II. Accounting Horizons, 15(2), 147-160. http://dx.doi.org/10.2308/acch.2001.15.2.147

Kesicki, F. (2010). Marginal Abatement Cost Curves for Policy Making-Expert-Based vs. Model-Derived Curves.

Kesicki, F., \& Strachan, N. (2011). Marginal abatement cost (MAC) curves: confronting theory and practice. Environmental Science \& Policy, 14(8), 1195-1204. http://dx.doi.org/10.1016/j.envsci.2011.08.004

Kolk, A., Levy, D., \& Pinkse, J. (2008). Corporate responses in an emerging climate regime: The institutionalization and commensuration of carbon disclosure. European Accounting Review, 17(4), 719-745. http://dx.doi.org/10.1080/09638180802489121

Kreuze, J. G., \& Newell, G. E. (1994). ABC and life-cycle costing for environmental expenditures. Management Accounting-New York, 75, 38.

Lindskog, E., Lundh, L., Berglund, J., Lee, Y. T., Skoogh, A., \& Johansson, B. (2011). A method for determining the environmental footprint of industrial products using simulation. Paper presented at the Simulation Conference (WSC), Proceedings of the 2011 Winter. http://dx.doi.org/10.1109/WSC.2011.6147926

Little, A. (2000). Total cost assessment methodology: Internal managerial decision making tool. Centre for waste reduction technologies, American Institute of Chemical Engineers publication, New York.

Lovell, H., \& MacKenzie, D. (2011). Accounting for carbon: the role of accounting professional organisations in governing climate change. Antipode, 43(3), 704-730. http://dx.doi.org/10.1111/j.1467-8330.2011.00883.x

Moran, D., MacLeod, M., Wall, E., Eory, V., Pajot, G., Matthews, R., ... Moxey, A. (2008). UK marginal abatement cost curves for the agriculture and land use, land-use change and forestry sectors out to 2022, with qualitative analysis of options to 2050 Final report to the Committee on Climate Change. Edinburgh: Scottish Agricultural College Commercial.

Nachtmann, H., \& Al-Rifai, M. H. (2004). An application of activity based costing in the air conditioner manufacturing industry. The Engineering Economist, 49(3), 221-236. http://dx.doi.org/10.1080/00137910490498933 
Norris, G. A. (2001). Integrating life cycle cost analysis and LCA. The international journal of life cycle assessment, 6(2), 118-120.

Parker, L. D. (1997). Accounting for environmental strategy: Cost management, control and performance $\begin{array}{lllll}\text { evaluation. Asia-Pacific Journal of Accounting, } & 4(2),\end{array}$ http://dx.doi.org/10.1080/10293574.1997.10510518

Pearce, D., \& Warford, J. (2001). World without End. Washington, DC.

Petcharat, N., \& Mula, J. M. (2010b). Can organizations meet their environment and social reporting obligations even in a financial crisis? Towards an effective sustainability management accounting system. Paper presented at the Global Business Conference 2010 Dubrovnik, Croatia.

Plesch, J. (2003). Environmental Strategies. Fachhochschule Reutlingen, DEUTSCHLAND.

Pramanik, A., Shil, N., \& Das, B. (2007). Environmental accounting and reporting With special reference to India.

Rivero, E. J. R., \& Emblemsvåg, J. (2007). Activity-based life-cycle costing in long-range planning. Review of Accounting and Finance, 6(4), 370-390. http://dx.doi.org/10.1108/14757700710835041

Roman, A. G., Roman, C., \& Manole, A. (2006). Environmental Management Accounting (EMA): Reflection of Environmental Factors in the Accounting Processes through the Identification of the Environmental Costs Attached to Products, Processes and Services.

Rubin, E. S., Rao, A. B., \& Berkenpas, M. B. (2001). A multi-pollutant framework for evaluating CO2 control options for fossil fuel power plants.

Scavone, G. M. (2006). Challenges in internal environmental management reporting in Argentina. Journal of Cleaner Production, 14(14), 1276-1285. http://dx.doi.org/10.1016/j.jclepro.2005.08.011

Schaltegger, S., \& Burritt, R. (2000). Contemporary environmental accounting: issues, concepts, and practice: Greenleaf Publishing.

Seidel, E., \& Thamhain, H. (2002). Managing environmental quality at the enterprise: the role of project management. Environmental Engineering and Policy, 3(1), 19-32.

Smith, J. B., Schneider, S. H., Oppenheimer, M., Yohe, G. W., Hare, W., Mastrandrea, M. D., ... Magadza, C. H. D. (2009). Assessing dangerous climate change through an update of the Intergovernmental Panel on Climate Change (IPCC)"reasons for concern". Proceedings of the National Academy of Sciences, 106(11), 4133-4137.

Staniskis, J. K., \& Stasiskiene, Z. (2006). Environmental management accounting in Lithuania: exploratory study of current practices, opportunities and strategic intents. Journal of Cleaner Production, 14(14), 1252-1261. http://dx.doi.org/10.1016/j.jclepro.2005.08.009

Sweeney, J., \& Weyant, J. (2008). Analysis of Measures to Meet the Requirements of California's Assembly Bill 32. Discussion draft, September 2008: Stanford, CA: Stanford University Precourt Institute for Energy Efficiency.

UN. (2009). United Nations Framework Convention on Climate Change. Decision 2/CP.15. Copenhagen Accord. United Nations Framework Convention on Climate Change.Bonn. Germany.

UNDSD. (2001a). Environmental Management Accounting Procedures and Principles, United Nations Division for Sustainable Development (UNDSD), New York.

UNDSD. (2001b). Environmental Management Accounting Procedures and Principles, United Nations Division for Sustainable Development (UNDSD), New York.

UNDSD. (2001c). Environmental Management Accounting Procedures and Principles, United Nations Division for Sustainable Development (UNDSD), New York.

Uno, K., \& Bartelmus, P. (1998). Environmental accounting in theory and practice, 11. Springer.

Wagner, F., Amann, M., Borken-Kleefeld, J., Cofala, J., Höglund-Isaksson, L., Purohit, P., ... Winiwarter, W. (2012). Sectoral marginal abatement cost curves: implications for mitigation pledges and air pollution co-benefits for Annex I countries. Sustainability Science, 1-16. http://dx.doi.org/10.1007/s11625-012-0167-3

Wahyuni, D. (2009). Environmental Management Accounting: Techniques and Benefits. Jurnal Akuntansi 
Universitas Jember, 7(1), 23-35.

Wilmshurst, T., \& Frost, G. (2001). The role of accounting and the accountant in the environmental management system. Business strategy and the environment, 10(3), 135-147.

Li, X. M. (2004). Theory and practice of environmental management accounting. International Journal of Technology Management \& Sustainable Development, 3(1), 47-57. http://dx.doi.org/10.1386/ijtm.3.1.47/0

Young, A. (2010). Greenhouse gas accounting: global problem, national policy, local fugitives. Sustainability Accounting, Management and Policy Journal, 1(1), 89-95. 